\title{
Relation of infant feeding to adult serum cholesterol concentration and death from ischaemic heart disease //
}

\author{
C H D Fall, D J P Barker, COsmond, P D Winter, P M \& Clark, C N L Hales
}

Abstract

Objective-To examine whether method of infant feeding is associated with adult serum lipid concentrations and mortality from ischaemic heart disease.

Design-Follow up study of men born during 1911-30.

Setting-Hertfordshire, England.

Subjects -5718 men, for 5471 of whom information on infant feeding had been recorded by health visitors and 1314 of whom had died. 485 of the men born during 1920-30 and still living in Hertfordshire who had blood lipid measurements.

Main outcome measures-Death from ischaemic heart disease; serum cholesterol and apolipoprotein concentrations.

Results $\mathbf{- 4 7 4}$ men had died from ischaemic heart disease. Standardised mortality ratios were 97 (95\% confidence interval 81 to 115) in men who had been breast fed and had not been weaned at 1 year, $79(69$ to 90 ) in breast fed men who had been weaned at 1 year, and 73 (59 to 89) in men who had been breast and bottle fed. Compared with men weaned before one year men not weaned had higher mean serum concentrations of total cholesterol (6.9 (not weaned) v 6.6 (weaned) $\mathrm{mmol} / \mathrm{l}$ ), low density lipoprotein cholesterol $(5.0 v 4.6 \mathrm{mmol} / \mathrm{l})$ and apolipoprotein $\mathrm{B}$ $(1.14 v 1.08 \mathrm{~g} / \mathrm{l})$. Men who had been bottle fed also had a high standardised mortality ratio for ischaemic heart disease $(95 ; 68$ to 130$)$ and high mean serum concentrations of total cholesterol $(7 \cdot 0 \mathrm{mmol} / \mathrm{l})$, low density lipoprotein cholesterol $(5.1 \mathrm{mmol} / \mathrm{l})$, and apolipoprotein $\mathrm{B}(1 \cdot 14 \mathrm{~g} / \mathrm{l})$. In all feeding groups serum apolipoprotein B concentrations were lower in men with higher birth weight and weight at 1 year.

Conclusions-Age of weaning and method of infant feeding may influence adult serum low density lipoprotein cholesterol concentrations and mortality from ischaemic heart disease. Adult serum apolipoprotein $B$ concentrations are related to growth in fetal life and infancy.

\section{Introduction}

There has been speculation that the high cholestero and saturated fat content of milk received by infants may influence lipid metabolism throughout life. ${ }^{1}$ In humans there is little evidence to support this since comparisons of serum cholesterol concentrations in people who were breast fed or bottle fed after birth have given conflicting results. ${ }^{2.7}$ Nevertheless, some observations give credibility to the speculation. An infant's serum cholesterol concentration, unlike that of an older child or an adult, is strongly related to its intake of cholesterol and saturated fat. ${ }^{4-10}$ Follow up studies of children have shown that serum cholesterol concentrations tend to track, so that children maintain their rank order by serum cholesterol concentration over several years. ${ }^{11-12}$ Tracking has been observed from the age of 6 months. Experiments in animals have clearly shown that different early feeding regimens can lead to permanent changes in serum lipid concentrations and in the metabolic activity of enzymes controlling cholesterol synthesis and excretion. ${ }^{13-15}$

We measured serum lipids in a group of men born in Hertfordshire, England, where the method of feeding of all babies was routinely recorded from 1911 onwards. ${ }^{16}$ The recorded information included whether infants were breast or bottle fed and whether they were weaned at 1 year of age. We have also examined death rates from ischaemic heart disease in relation to method of infant feeding.

\section{Subjects and methods}

In Hertfordshire from 1911 onwards each birth was notified by the attending midwife and the birth weight recorded. ${ }^{16} \mathrm{~A}$ health visitor saw the babies at home periodically through infancy (the first year of life) and recorded how each baby was fed, using one of three categories: breast feeding, bottle feeding, or a combination of breast and bottle feeding. When children were 1 year old their weight, whether or not they were weaned, and how many teeth had erupted were recorded. Weights were measured in pounds $(1 \mathrm{lb}=$ $0.45 \mathrm{~kg}$ ) and were often rounded to the nearest half pound. We have therefore used the original units.

We traced $5718(72 \%)$ of the singleton boys born in six districts of east Hertfordshire during 1911-30 who had birth weight and weight at 1 year recorded and who had survived childhood. For 5471 of them the method of infant feeding was recorded. Copies of death certificates for those who had died were sent to us by the NHS central registry, Southport. We analysed death rates from ischaemic heart disease (ICD (ninth revision) 410-414) and all non-circulatory disease (all causes excluding ICD 390-459) in relation to birth weight, weight at 1 year, and method of infant feeding. The numbers of deaths were compared with those expected from national rates for men of corresponding age and year of birth and were expressed as standardised mortality ratios with the national average for England and Wales as 100 .

There were 1157 men who were born during 1920-30 and who still lived in the six districts. As previously described 845 of them (73\%) agreed to be interviewed at home and were visited by one of four fieldworkers. ${ }^{17}$ The fieldworkers had not seen the infant data recorded for the men. Blood pressure, height, weight, and waist and hip circumferences were measured. ${ }^{18}$ Information about each man's social history and smoking and drinking habits was obtained. Father's occupation was used to define social class at birth, and current social class was derived from the man's occupation. ${ }^{19}$ After the interview the men were asked if they would be willing to attend a local clinic to have blood samples taken. They were asked to attend twice: once after

biochemist

C N Hales, FRCP, professor 
fasting overnight for 12 hours and once for a nonfasting sample. Men known to have diabetes were excluded. In all, 485 (57\%) men provided fasting blood samples, of whom 431 also provided non-fasting samples.

The fasting blood samples were analysed for serum total cholesterol, high density lipoprotein cholesterol, triglyceride, apolipoproteins $\mathrm{Al}$ and $\mathrm{B}$, and $\mathrm{Lp}(\mathrm{a})$ lipoprotein concentrations. The non-fasting samples were analysed for only total cholesterol. Serum total cholesterol, high density lipoprotein cholesterol, and triglyceride concentrations were measured by standard enzymatic methods. ${ }^{20-23}$ Interassay coefficients of variation for these assays were in the range $1 \cdot 7 \%$ to $2 \cdot 7 \%$. Low density lipoprotein cholesterol concentration was derived by the Friedwald-Fredrickson formula. ${ }^{24} \mathrm{Apo}$ lipoprotein $\mathrm{Al}$ and $\mathrm{B}$ concentrations were measured by immunoturbimetric assays with interassay coefficients of variation of less than $5 \% .{ }^{25} \mathrm{Lp}(\mathrm{a})$ lipoprotein concentration was measured by immunoenzymometric assay (Enzyquick, Immuno, Sevenoaks) with an interassay coefficient of variation of $11 \% .{ }^{26}$

Serum concentrations of triglyceride, apolipoproteins $\mathrm{Al}$ and $\mathrm{B}$, and $\mathrm{Lp}(\mathrm{a})$ lipoprotein had skewed distributions and we transformed them using logarithms. The geometric standard deviation is the antilog of the standard deviation measured on the log scale. We analysed the data using tabulation of means, multiple linear regression, and two sample $t$ tests. Standardised mortality ratios were calculated by the method of person years. ${ }^{2}$

\section{Results}

Of the 5471 men, 1381 had been both breast and bottle fed, 3733 had been exclusively breast fed, and 357 had been exclusively bottle fed. Only 2592 (69\%)

TABLE I-Standardised mortality ratios for ischaemic heart disease in 5471 men born in east Hertfordshire, 1911-30, according to method of feeding as infants. (Numbers of deaths are in parentheses)

\begin{tabular}{|c|c|c|c|c|c|}
\hline \multirow[b]{2}{*}{ Weight at 1 year $(\mathrm{lb})$} & \multirow[b]{2}{*}{$\begin{array}{l}\text { Breast and } \\
\text { bottle fed }\end{array}$} & \multicolumn{2}{|c|}{ Breast fed } & \multirow[b]{2}{*}{ Bottle fed } & \multirow[b]{2}{*}{ All } \\
\hline & & $\begin{array}{l}\text { Weaned at } \\
1 \text { year }\end{array}$ & $\begin{array}{l}\text { Not weaned } \\
\text { at } 1 \text { year }\end{array}$ & & \\
\hline $\begin{array}{l}\leqslant 18 \\
-20 \\
-22 \\
-24 \\
-26 \\
>26\end{array}$ & $\begin{array}{l}87(8) \\
88(21) \\
90(37) \\
66(22) \\
42(8) \\
26(2)\end{array}$ & $\begin{array}{l}93(14) \\
93(39) \\
92(77) \\
69(51) \\
67(24) \\
23(3)\end{array}$ & $\begin{array}{r}140(10) \\
95(26) \\
121(55) \\
65(21) \\
87(13) \\
73(4)\end{array}$ & $\begin{array}{c}126(4) \\
97(6) \\
75(9) \\
109(13) \\
104(6) \\
50(1)\end{array}$ & $\begin{array}{c}104(36) \\
93(92) \\
97(178) \\
71(107) \\
68(51) \\
36(10)\end{array}$ \\
\hline $\begin{array}{l}\text { All weights } \\
95 \% \text { Confidence interval } \\
\text { Ratio for non-circulatory }\end{array}$ & $\begin{array}{l}73(98) \\
59 \text { to } 89\end{array}$ & $\begin{array}{l}79(208) \\
69 \text { to } 90\end{array}$ & $\begin{array}{l}97(129) \\
81 \text { to } 115\end{array}$ & $\begin{array}{l}95(39) \\
68 \text { to } 130\end{array}$ & $\begin{array}{l}83(474) \\
75 \text { to } 90\end{array}$ \\
\hline $\begin{array}{l}\text { Ratio for non-circulatory } \\
\text { disease } \\
95 \% \text { Confidence interval }\end{array}$ & $\begin{array}{l}74(147) \\
62 \text { to } 87\end{array}$ & $\begin{array}{l}84(329) \\
75 \text { to } 94\end{array}$ & $\begin{array}{l}85(166) \\
73 \text { to } 99\end{array}$ & $\begin{array}{l}69(42) \\
50 \text { to } 94\end{array}$ & $\begin{array}{l}81(684) \\
75 \text { to } 87\end{array}$ \\
\hline
\end{tabular}

TABLE II -Mean serum lipid concentrations, height, body mass index, percentage of smokers and men of low social class in 485 men aged 59-70 according to infant feeding

\begin{tabular}{|c|c|c|c|c|c|c|}
\hline & \multirow[b]{2}{*}{$\begin{array}{l}\text { Breast and } \\
\text { bottle fed } \\
(\mathrm{n}=116)\end{array}$} & \multicolumn{2}{|c|}{ Breast fed } & \multirow[b]{2}{*}{$\begin{array}{l}\text { Bottle fed } \\
(\mathbf{n}=25)\end{array}$} & \multirow[b]{2}{*}{$\begin{array}{l}\text { All groups } \\
\text { (No of men) } \\
(n=485)\end{array}$} & \multirow[b]{2}{*}{$\begin{array}{l}\text { Standard } \\
\text { deviation }\end{array}$} \\
\hline & & $\begin{array}{l}\text { Weaned } \\
\text { at } 1 \text { year } \\
(\mathrm{n}=253)\end{array}$ & $\begin{array}{l}\text { Not weaned } \\
\text { at } 1 \text { year } \\
(\mathrm{n}=91)\end{array}$ & & & \\
\hline Cholesterol $(\mathrm{mmol} / \mathrm{l})$ & $6 \cdot 6$ & $6 \cdot 6$ & $6 \cdot 9^{\star}$ & $7 \cdot 0^{\star}$ & $6 \cdot 7(485)$ & $1 \cdot 2$ \\
\hline Non-fasting cholesterol $(\mathrm{mmol} / \mathrm{l})$ & $6 \cdot 4$ & $6 \cdot 4$ & $6 \cdot 9 \star \star$ & $7 \cdot 1^{\star \star}$ & $6 \cdot 5(431)$ & $1 \cdot 2$ \\
\hline $\begin{array}{l}\text { Low density lipoprotein } \\
\text { cholesterol }(\mathrm{mmol} / \mathrm{l})\end{array}$ & $4 \cdot 6$ & $4 \cdot 6$ & $5 \cdot 0^{\star \star}$ & $5 \cdot 1^{\star}$ & $4 \cdot 7(470)$ & $1 \cdot 1$ \\
\hline $\begin{array}{l}\text { High density lipoprotein } \\
\text { cholesterol }(\mathrm{mmol} / \mathrm{l})\end{array}$ & $1 \cdot 2$ & $1 \cdot 2$ & $1 \cdot 2$ & $1 \cdot 2$ & $1 \cdot 2(470)$ & $0 \cdot 3$ \\
\hline $\begin{array}{l}\text { Low density lipoprotein:high } \\
\text { density lipoprotein }\end{array}$ & $3 \cdot 8$ & $3 \cdot 8$ & $4 \cdot 2^{\star \star}$ & $4 \cdot 2$ & $3.9(470)$ & $1 \cdot 5$ \\
\hline Triglyceride $(\mathrm{mmol} / \mathrm{l}) \dagger$ & $1 \cdot 4$ & 1.4 & 1.5 & 1.4 & $1 \cdot 4(485)$ & 1.6 \\
\hline Apolipoprotein Al $(\mathrm{g} / \mathrm{l}) \dagger$ & $1 \cdot 31$ & $1 \cdot 30$ & $1 \cdot 29$ & $1 \cdot 35$ & $1 \cdot 30(466)$ & $1 \cdot 2$ \\
\hline Apolipoprotein B $(g / 1) \dagger$ & 1.08 & 1.08 & $1 \cdot 14$ & $1 \cdot 14$ & $1.09(464)$ & $1 \cdot 3$ \\
\hline $\mathrm{Lp}$ (a) lipoprotein $(\mathrm{mg} / \mathrm{l}) t$ & 92 & 100 & 96 & 83 & $97(469)$ & 3.6 \\
\hline Height $(m)$ & 1.71 & 1.72 & 1.72 & 1.72 & $1 \cdot 72(485)$ & 0.07 \\
\hline Body mass index $\left(\mathrm{kg} / \mathrm{m}^{2}\right)$ & $26 \cdot 5$ & $27 \cdot 0$ & $27 \cdot 1$ & $27 \cdot 1$ & $26 \cdot 9(485)$ & 3.5 \\
\hline$\%$ Current smokers & 23 & 28 & 27 & 28 & $27(482)$ & 44 \\
\hline$\%$ Current social class IV or V & 25 & 24 & 29 & 24 & $25(480)$ & 43 \\
\hline$\%$ Social class IV or V at birth & 46 & 48 & $64^{\star \star \star}$ & 50 & $51(458)$ & 50 \\
\hline
\end{tabular}

${ }^{\star} \mathrm{p}<0.05,{ }^{\star \star} \mathrm{p}<0.01$, comparison with breast and bottle fed and breast fed and weaned group

$\dagger$ Logarithms were used in the analysis therefore means and standard deviations are geometric of the men who had been exclusively breast fed had been weaned at 1 year compared with $1244(90 \%)$ of those who had been breast and bottle fed and $336(94 \%)$ of those who had been exclusively bottle fed.

A total of 1314 men had died, of whom 474 had died of ischaemic heart disease. The death rate from this disease was below the national average, the overall standardised mortality ratio being 83 . Analysis according to method of infant feeding showed that the standardised mortality ratio was 73 in the men who had been breast and bottle fed, 85 in the men who had been exclusively breast fed, and 95 in the men who had been exclusively bottle fed. We divided the exclusively breast fed men according to whether or not they had been weaned at 1 year. The standardised mortality ratio in those who had been weaned was 79 compared with 97 in those who had not been weaned (table I). In contrast with these differences in mortality from ischaemic heart disease there were no significant differences in mortality from non-circulatory disease (table I).

As we have shown previously, ${ }^{16}$ standardised mortality ratios fell with increasing weight at 1 year (table I). This trend was seen in each feeding group. In each weight group, however, standardised mortality ratios tended to be higher in men who had been breast fed and had not been weaned at 1 year and in those who had been exclusively bottle fed. In all feeding groups combined standardised mortality ratios fell with in creasing birth weight (from 105 in those who weighed $5.5 \mathrm{lb}$ or less at birth to 81 in those who weighed more than $9.5 \mathrm{lb}$ ), though the fall was not so great as with weight at 1 year. In men who had been breast fed and had not been weaned at 1 year, however, standardised mortality ratios rose with increasing birth weight.

The ages of the 485 men who still lived in the six districts of east Hertfordshire ranged from 59 to 70 (mean 64) years; 116 had been breast and bottle fed, 344 exclusively breast fed, and 25 exclusively bottle fed. Only $253(74 \%)$ of the men who had been exclusively breast fed had been weaned at 1 year compared with $102(88 \%)$ of those who had been breast and bottle fed and $25(100 \%)$ of those who had been exclusively bottle fed.

Men who had been breast fed and had not been weaned at 1 year, and those who had been exclusively bottle fed, had higher serum concentrations of total cholesterol in fasting and non-fasting samples, and of low density lipoprotein cholesterol, and higher ratios of low density lipoprotein to high density lipoprotein cholesterol than men in the other two feeding groups (table II). Differences in apolipoprotein B concentrations showed the same pattern as those in total and low density lipoprotein cholesterol, though they were not significant.

There were no differences between feeding groups in mean serum concentrations of high density lipoprotein cholesterol, triglycerides, apolipoprotein Al, and $L p(a)$ lipoprotein or in mean height and body mass index (table II). The percentages of men who were current smokers or who were in social class IV or V were similar in all infant feeding groups. Despite the similarity in current social class, a higher percentage of men who had been breast fed and had not been weaned at 1 year had been born into families of social class IV or V. Table III shows, however, that the higher concentrations of low density lipoprotein cholesterol in the men in this feeding group were found for all social classes at birth. Findings for total cholesterol and apolipoprotein B were similar.

Men who had been breast and bottle fed and men who had been breast fed and weaned at 1 year had similar mortality from ischaemic heart disease (table I) and mean values of all variables in table II. Only 14 of the breast and bottle fed men had not been weaned at 
TABLE III - Mean serum low density lipoprotein cholesterol concentration (mmol/l) in men aged 59-70 according to infant feeding and social class at birth

\begin{tabular}{|c|c|c|c|c|c|c|}
\hline \multirow[b]{2}{*}{ Social class at birth } & \multirow[b]{2}{*}{$\begin{array}{c}\text { Breast and } \\
\text { bottle }\end{array}$} & \multicolumn{2}{|c|}{ Breast fed } & \multirow[b]{2}{*}{ Bottle } & \multirow[b]{2}{*}{$\begin{array}{l}\text { All groups } \\
\text { (No of men) }\end{array}$} & \multirow[b]{2}{*}{$\begin{array}{l}\text { Standard } \\
\text { deviation }\end{array}$} \\
\hline & & $\begin{array}{l}\text { Weaned } \\
\text { at } 1 \text { year }\end{array}$ & $\begin{array}{l}\text { Not weaned } \\
\text { at } 1 \text { year }\end{array}$ & & & \\
\hline I, II, III (Non-manual) & $4 \cdot 8$ & $4 \cdot 6$ & $5 \cdot 1$ & 4.9 & $4 \cdot 7(62)$ & $1 \cdot 0$ \\
\hline III (Manual) & 4.5 & 4.7 & $5 \cdot 0$ & $5 \cdot 6$ & $4 \cdot 7(157)$ & $1 \cdot 1$ \\
\hline IV, V & $4 \cdot 6$ & $4 \cdot 6$ & $5 \cdot 0$ & $5 \cdot 0$ & $4.7(225)$ & $1 \cdot 2$ \\
\hline All classes & $4 \cdot 6$ & $4 \cdot 6$ & $5 \cdot 0$ & $5 \cdot 2$ & $4 \cdot 7(444)$ & $1 \cdot 1$ \\
\hline
\end{tabular}

TABLE IV-Mean fasting serum cholesterol concentration ( $\mathrm{mmol} / \mathrm{l}$ ) in men aged $59-70$ according to weight at 1 year, birth weight, and whether weaned at 1 year. (Numbers of men are in parentheses)

\begin{tabular}{|c|c|c|}
\hline & Weaned & Not weane \\
\hline \multicolumn{3}{|c|}{ Weight at 1 year $(\mathrm{lb})$ : } \\
\hline$\geqslant 18$ & $6 \cdot 7(20)$ & $7 \cdot 5(5)$ \\
\hline & $6 \cdot 7(53)$ & \\
\hline-22 & $6 \cdot 7($ & $6.8(35)$ \\
\hline-24 & $6.5(107)$ & $6 \cdot 6(19)$ \\
\hline-26 & $6 \cdot 2(52)$ & $6.9(9)$ \\
\hline$>26$ & $6.9(2$ & $7 \cdot 1(6$ \\
\hline \multicolumn{3}{|c|}{ Birth weight (lb): } \\
\hline$-5=5$ & 65 & $6 \cdot 1$ \\
\hline-6 . & $6.9(41)$ & 6.4( \\
\hline-7 & $6 \cdot 6(109)$ & $6 \cdot 6$ \\
\hline-8 & $6 \cdot 5(106)$ & $7 \cdot 3(27)$ \\
\hline-9 & $6 \cdot 7(54)$ & $7 \cdot 0(14)$ \\
\hline$>9$ & $6 \cdot 2(27)$ & $7 \cdot 2(6)$ \\
\hline
\end{tabular}

All weights $6.6(355) \quad 6.9(91)$ Standard

deviation $\quad 1.2 \quad 1.3$
1 year. We excluded these 14 and combined the remaining 102 with the 253 breast fed men who had been weaned at 1 year. This defined a "weaned" group, which we contrasted with the 91 men who were breast fed and not weaned at 1 year, the "not weaned" group. Because of the small numbers of men who were exclusively bottle fed we excluded them from further analysis.

Table IV shows mean fasting serum cholesterol concentrations according to weight at 1 year and birth weight. In the weaned group there were no trends with weight at 1 year or with birth weight. The mean fasting serum cholesterol concentrations in the not weaned group rose with increasing birth weight. In the not weaned group a simultaneous regression analysis with weight at 1 year and birth weight showed that serum cholesterol concentration fell by $0.15 \mathrm{mmol} / \mathrm{l}$ for every pound increase in weight at 1 year and rose by $0.43 \mathrm{mmol} / \mathrm{l}$ for every pound increase in birth weight (table V). Mean fasting cholesterol concentrations were higher in men with higher body mass indices $(p=0.02)$ and waist to hip ratios $(p=0.005)$. They did not vary in relation to age, smoking, alcohol consumption, or social class, either currently or at birth. Adjustment for body mass index and waist to hip ratio did not change the trends in mean cholesterol concentration shown in table IV.

In the not weaned group the trends in non-fasting serum cholesterol, low density lipoprotein cholesterol, and apolipoprotein B concentrations were similar to those in fasting cholesterol concentrations (table V). In table VI the men are divided into three roughly equal groups according to weight at 1 year, and three equal groups according to birth weight. Among men in the not weaned group the highest low density lipoprotein cholesterol value was $5.7 \mathrm{mmol} / \mathrm{l}$ in men who weighed more than $8.25 \mathrm{lb}$ at birth but $21 \mathrm{lb}$ or less at 1 year. In the weaned group the mean low density lipoprotein cholesterol concentrations were more evenly distributed according to birth weight and weight at 1 year. In contrast with findings for total cholesterol and low density lipoprotein cholesterol, mean apolipoprotein B concentrations in the weaned group fell with increasing weight at 1 year and birth weight (table VII).

Mean systolic blood pressures in the weaned and not weaned groups were similar: $164 \mathrm{~mm} \mathrm{Hg}$ and $167 \mathrm{~mm} \mathrm{Hg}$ respectively. Mean diastolic blood pressure was $90 \mathrm{~mm} \mathrm{Hg}$ in both groups. We have previously analysed plasma concentrations of fibrinogen, factor VII, and glucose in this sample of men, ${ }^{18} 28$ though without separate analysis by feeding group. Mean concentrations were similar in the weaned and not weaned groups: fibrinogen $3.03 \mathrm{~g} / \mathrm{l}$ (weaned) and

TABLE $\mathrm{v}-$ Regression of serum lipid concentrations on birth weight and weight at 1 year simultaneously in men aged 59-70 who had not been weaned at 1 year

\begin{tabular}{|c|c|c|c|c|}
\hline \multirow[b]{2}{*}{ Dependent variable } & \multicolumn{2}{|l|}{ Birth weight (lb) } & \multicolumn{2}{|c|}{ Weight at 1 year $(\mathrm{lb})$} \\
\hline & $\begin{array}{c}\text { Regression coefficient } \\
(95 \% \text { confidence interval })\end{array}$ & $\mathrm{p}$ Value & $\begin{array}{l}\text { Regression coefficient } \\
(95 \% \text { confidence interval })\end{array}$ & $\mathrm{p}$ Value \\
\hline Fasting cholesterol $(\mathrm{mmol} / \mathrm{l})$ & $0.43(0.19$ to 0.68$)$ & $<0.001$ & $-0.15(-0.27$ to -0.04$)$ & 0.01 \\
\hline Non-fasting cholesterol $(\mathrm{mmol} / \mathrm{l})$ & $0.34(0.04$ to 0.64$)$ & 0.03 & $-0.22(-0.35$ to -0.09$)$ & 0.001 \\
\hline $\begin{array}{l}\text { Low density lipoprotein cholesterol } \\
(\mathrm{mmol} / \mathrm{l})\end{array}$ & $0.39(0.16$ to 0.62$)$ & 0.001 & $-0 \cdot 12(-0 \cdot 22$ to $-0 \cdot 01)$ & $0 \cdot 04$ \\
\hline Apolipoprotein B $(\log \mathrm{g} / \mathrm{l})$ & $0.06(0.01$ to 0.11$)$ & 0.03 & $-0.04(-0.06$ to -0.01$)$ & 0.007 \\
\hline
\end{tabular}

$3.05 \mathrm{~g} / \mathrm{l}$ (not weaned); factor VII $108 \%$ of standard and $108 \%$ of standard; glucose two hours after a $75 \mathrm{~g}$ oral glucose load $6.6 \mathrm{mmol} / \mathrm{l}$ and $6.5 \mathrm{mmol} / \mathrm{l}$. The percentages of men with impaired glucose tolerance or newly diagnosed diabetes mellitus were $24 \%$ in the weaned group and $25 \%$ in the not weaned group.

We examined the early weight and number of teeth at 1 year in the weaned and not weaned group. Mean birth weights were identical $(7.9 \mathrm{lb})$ but mean weight at

TABLE VI-Mean serum low density lipoprotein cholesterol concentration (mmol/l) in men aged 59-70 according to weight at 1 year, birth weight, and whether weaned at 1 year. (Numbers of men are in parentheses)

\begin{tabular}{|c|c|c|c|c|}
\hline \multirow[b]{2}{*}{ Birth weight (lb) } & \multicolumn{4}{|c|}{ Weight at 1 year $(\mathrm{lb})$} \\
\hline & $\leqslant 21$ & -23 & $>23$ & All \\
\hline $\begin{array}{l}\text { Weaned: } \\
\quad \leqslant 7 \\
-8.25 \\
>8.25\end{array}$ & $\begin{array}{l}4 \cdot 8(45) \\
4 \cdot 8(41) \\
4 \cdot 8(22)\end{array}$ & $\begin{array}{l}4 \cdot 8(29) \\
4 \cdot 5(47) \\
4 \cdot 6(45)\end{array}$ & $\begin{array}{l}4 \cdot 6(10) \\
4 \cdot 5(39) \\
4.5(64)\end{array}$ & $\begin{array}{l}4 \cdot 8(84) \\
4 \cdot 6(127) \\
4 \cdot 6(131)\end{array}$ \\
\hline All` & $4 \cdot 8(108)$ & $4 \cdot 6(121)$ & $4 \cdot 5(113)$ & $4 \cdot 6(342)$ \\
\hline $\begin{array}{c}\text { Not weaned: } \\
\leqslant 7 \\
-8.25 \\
>8.25\end{array}$ & $\begin{array}{l}4 \cdot 8(18) \\
4 \cdot 9(13) \\
5 \cdot 7(8)\end{array}$ & $\begin{array}{l}4 \cdot 1(7) \\
4 \cdot 9(12) \\
5 \cdot 3(9)\end{array}$ & $\begin{array}{l}3 \cdot 9(1) \\
5 \cdot 1(10) \\
5 \cdot 2(12)\end{array}$ & $\begin{array}{l}4 \cdot 6(26) \\
4.9(35) \\
5.4(29)\end{array}$ \\
\hline All & $5 \cdot 0(39)$ & $4 \cdot 8(28)$ & $5 \cdot 1(23)$ & $5 \cdot 0(90)$ \\
\hline
\end{tabular}

$\star$ Overall standard deviation $=1 \cdot 1 . \quad$ †Overall standard deviation $=1 \cdot 2$

TABLE VII-Mean fasting serum apolipoprotein B concentration $(g / l)$ in men aged 59-70 according to weight at 1 year, birth weight, and whether weaned at one year. (Numbers of men are in parentheses)

\begin{tabular}{|c|c|c|c|}
\hline & Weaned & Not weaned & All men \\
\hline $\begin{array}{l}\text { Weight at } 1 \text { year }(\mathrm{lb}) \text { : } \\
\leqslant 18 \\
-20 \\
-22 \\
-24 \\
-26 \\
>26\end{array}$ & $\begin{array}{l}1.08(19) \\
1.18(52) \\
1.09(99) \\
1.06(104) \\
1.01(47) \\
1.05(20)\end{array}$ & $\begin{array}{l}1 \cdot 30(5) \\
1 \cdot 24(15) \\
1 \cdot 14(33) \\
1 \cdot 08(18) \\
1 \cdot 11(8) \\
1 \cdot 05(6)\end{array}$ & $\begin{array}{l}1 \cdot 12(24) \\
1.19(67) \\
1.10(132) \\
1.06(122) \\
1.03(55) \\
1.05(26)\end{array}$ \\
\hline $\begin{array}{l}\text { Birth weight (lb): } \\
\quad \leqslant 5.5 \\
-6.5 \\
-7.5 \\
-8.5 \\
-9.5 \\
>9.5\end{array}$ & $\begin{array}{l}1 \cdot 13(18) \\
1 \cdot 20(39) \\
1.08(104) \\
1.06(102) \\
1.05(51) \\
1.01(27)\end{array}$ & $\begin{array}{l}1 \cdot 12(1) \\
1 \cdot 09(15) \\
1 \cdot 12(25) \\
1 \cdot 21(26) \\
1 \cdot 15(13) \\
1 \cdot 08(5)\end{array}$ & $\begin{array}{l}1.13(19) \\
1.17(54) \\
1.08(129) \\
1.09(128) \\
1.07(64) \\
1.02(32)\end{array}$ \\
\hline $\begin{array}{l}\text { All weights } \\
\text { Geometric standard } \\
\text { deviation }\end{array}$ & $\begin{array}{c}1.08(341) \\
1 \cdot 31\end{array}$ & $\begin{array}{c}1 \cdot 14(85) \\
1 \cdot 29\end{array}$ & $\begin{array}{c}1.09(426) \\
1.31\end{array}$ \\
\hline
\end{tabular}

1 year was lower in the not weaned group $(22.6 \mathrm{lb}$ weaned $v 22 \cdot 3 \mathrm{lb}$ not weaned). This difference was not significant. Mean numbers of teeth were, however, significantly lower in the not weaned group $(6.9$ weaned $v 6 \cdot 2$ not weaned). The difference between the two groups in numbers of teeth was greatest in men who had been heaviest at birth. In the three birth weight groups $\leqslant 7 \mathrm{lb},>7-8.25 \mathrm{lb}$, and $>8.25 \mathrm{lb}$, the mean numbers of teeth at 1 year in the weaned group were $6 \cdot 3,6 \cdot 6$, and $7 \cdot 6$ respectively compared with $5 \cdot 8$, $6 \cdot 3$, and $6 \cdot 2$ in the not weaned group.

\section{Discussion}

We have shown that serum lipid concentrations among adult men and death rates from ischaemic heart disease are related to the method of infant feeding. Among 5471 men born in part of one county in England around 70 years ago those who had been breast fed and had not been weaned at 1 year and those who had been exclusively bottle fed from birth had higher death rates from ischaemic heart disease (table I). Examination of those still living in the county showed that these two groups of men also had higher serum total cholesterol, low density lipoprotein cholesterol, and apolipoprotein B concentrations (table II). Each of these is known to be associated with 
increased risk of ischaemic heart disease. Serum cholesterol concentrations in these two groups of men were raised in fasting and non-fasting blood samples.

The subsample of men whose serum cholesterol concentrations were measured comprised men who were born in east Hertfordshire during 1920-30 and still lived there. Since our analysis was based on internal comparisons the selection of the sample would introduce bias only if the relations between infant feeding and serum cholesterol were different in those selected and not selected. This is unlikely. There were no differences in mean birth weight, weight at 1 year, or percentages of men in each infant feeding group between the 485 men examined and the total group of 5471 men who were traced.

The health visitors in Hertfordshire recorded that each baby was or was not weaned at 1 year. The term weaned can imply either that breast feeding has stopped or that solid food has been introduced. The evidence from the Hertfordshire chief health visitor's annual reports, anecdotal evidence from health visitors who worked in Hertfordshire around this period, and contemporary records in Derbyshire (unpublished) suggest that weaned usually meant stopping of breast feeding. In her annual reports the chief health visitor for Hertfordshire quoted percentages of breast fed babies weaned at 12 months but gave no comparable information for bottle fed babies, presumably because the word did not usually apply..$^{29}$

In our analysis the not weaned group comprised men who had been exclusively breast fed. It did not include the few men who had been bottle fed or breast and bottle fed and who had not been weaned at 1 year. Men in the not weaned group were therefore still receiving some breast milk at 1 year, but we do not know how much or whether they had solid food as well.

In England at the beginning of the century breast feeding was continued for longer than is now usual but commonly stopped at around 9 months and usually before 1 year. ${ }^{30} 31$ More of the men in Hertfordshire who were not weaned at 1 year were born into low social class families. Anecdotal evidence from Hertfordshire suggests that women in lower social classes prolonged breast feeding beyond 1 year as a form of contraception. It could be argued that the raised low density lipoprotein cholesterol concentrations in these men were a consequence of different diet in later life rather than of infant feeding. However, they had raised low density lipoprotein cholesterol concentrations regardless of which social class they had been born into (table III) or of their social class at the time of the survey. Furthermore, these men were similar to those in the other infant feeding groups in respect of all other cardiovascular risk factors, including body mass index and factor VII concentration, which are known to be influenced by adult diet. ${ }^{32}$

\section{EFFECT OF PROLONGED BREAST FEEDING}

Our findings suggest that in babies born 70 years ago who were breast fed and weaned relatively late a process was established which led to raised serum concentrations of low density lipoprotein cholesterol and increased death rates from ischaemic heart disease in adult life. This process was not linked to high density lipoprotein cholesterol, triglyceride, apolipoprotein $\mathrm{Al}$, or $\mathrm{Lp}(\mathrm{a})$ lipoprotein concentrations. Findings from previous studies in Hertfordshire and Preston suggest that adult blood pressure and concentrations of fibrinogen, factor VII, and glucose are partly determined or programmed during critical periods in fetal life and infancy. The critical period may differ for each variable and may be linked to times of rapid growth of the blood vessels, liver, and endocrine pancreas. ${ }^{182833}$ The regulation of serum lipid and lipoprotein concentrations involves several tissues, most importantly the liver and gut. Mechanisms by which late weaning of infants may programme lipid metabolism in adults and the tissues which are programmed are a matter for speculation.

Experiments in animals have shown that manipulation of the diets of newborn and weanling animals can produce long term increases in serum lipid, lipoprotein, and apolipoprotein concentrations and changes in the activity of the rate limiting enzymes hydroxymethylglutaryl coenzyme A reductase (cholesterol synthesis) and $7 \alpha$-hydroxylase (bile acid synthesis). ${ }^{13-15}$ Though it is unclear which nutrients effect these long term changes, the experiments are clear demonstrations of programming. Experiments with the timing of weaning have shown that premature weaning can raise serum cholesterol concentrations in adult animals. ${ }^{34} 35$ There have been no studies on the long term effects of late weaning.

\section{INFANT FOODS}

Different infant foods are known to have different immediate effects in the human infant. Babies fed on breast milk or cows' milk have higher serum cholesterol concentrations than those fed on modern formula milks, which have a lower cholesterol content and a higher polyunsaturated:saturated fatty acid ratio..$^{9-10}$ This sensitivity of infants to the fat content of the diet contrasts with the low correlation between dietary fat intake and serum cholesterol concentrations in older children and adults. ${ }^{46} 37$

Different infant foods also affect the excretion of bile acids. Breast fed and formula fed infants differ in the quantity of bile acids excreted and in the timing of appearance of secondary bile acids, which depends on the action of gut flora. ${ }^{38}$ Breast milk contains several hormones and growth factors that can influence lipid metabolism, including thyroid hormones and steroids. ${ }^{39}$ Though the effect of these maternal hormones on the infant is unknown, experiments have shown that breast fed baboons have different circulating concentrations of triiodothyronine and cortisol than bottle fed ones ( $G$ Mott, personal communication). Babies in Hertfordshire who were not weaned at 1 year would have continued to have a high fat intake from milk and also maternal hormones.

Breast milk provides ideal nourishment for the young infant, but there is evidence that some babies who are exclusively breast fed after 6 months receive inadequate energy. ${ }^{+1}$ Human breast milk contains low iron concentrations, and exclusively breast fed babies commonly develop low iron stores in the latter half of infancy. ${ }^{42}$ Breast milk may also be deficient of vitamins, notably vitamin $\mathrm{D}$, if the mother is poorly nourished. ${ }^{43}$ In Hertfordshire infants who were not weaned weighed less at 1 year and had fewer teeth than those who were weaned. This may be evidence of poorer nutrition in the not weaned group, although we cannot say whether these differences were due to late weaning or a cause of it. Among men who had not been weaned it was the men with higher birth weights but lower weights at 1 year who had the higher death rates from ischaemic heart disease. They also had higher serum total and low density lipoprotein cholesterol concentrations (tables IV, V, and VI). One interpretation of this is that larger babies tended to outgrow an inadequate supply of nutrients.

The men who had been exclusively bottle fed, who comprised only $5 \%$ of the sample, were similar to the not weaned group in having higher death rates from ischaemic heart disease and higher low density lipoprotein cholesterol and apolipoprotein B concentrations. We do not know what was contained in the bottle feeds because this was not specified in the Hertfordshire records. Bottle foods available 70 years ago included patent preparations of dried cows' milk, 
unmodified cows' milk, diluted condensed milk, and patent foods made from wheatflour or arrowroot. ${ }^{44}$ Modern formula milks differ from these foods: they are fortified with iron and vitamins; the fat content is mainly unsaturated; and the electrolyte content is similar to that of breast milk. It is therefore difficult to assess the relevance of these findings for bottle fed babies today.

We have shown that men who had higher birth weights and weights at 1 year had lower serum concentrations of apolipoprotein B. This was independent of whether or not they had been breast fed beyond 1 year (table VII). A relation between birth weight and apolipoprotein B concentrations has been shown in infants, though in the opposite direction. ${ }^{46}$

\section{CONCLUSIONS}

This is the first study of the relation between breast and bottle feeding, age at weaning, and lipid and apolipoprotein concentrations in middle to late life. Previous studies in humans have been limited to children and young adults and related serum cholesterol concentrations to breast or bottle feeding in infancy. ${ }^{2-7}$ The results have been inconclusive and largely negative. Our data suggest that age of weaning, and possibly type of milk, may permanently influence serum low density lipoprotein cholesterol concentrations and death rates from ischaemic heart disease.

We thank all the men who gave us their time; Hertfordshire County archives, which preserved the records; the staff of the NHS central register, Southport, and Hertfordshire Family Health Services Authority who helped trace the men; and Dr I Clarke for much local help. The fieldwork was coordinated by P Harwood and done by S Haynes, P Howell, R Rosenthal, and $S$ Wolfe. We thank $H$ Whiteside, C Carr, and staff of the NHS section of the department of clinical biochemistry, Addenbrooke's Hospital, for technical help and B Newland of Princess Alexandra Hospital, Harlow, for storing samples. The study was funded by the Medical Research Council, the British Heart Foundation, the Dunhill Medical Trust, The Wessex Medical Trust, the British Diabetic Association, and Lilly Research Laboratories.

1 Chapin HD. Biology as the basic principle in infant feeding. Postgraduat (NY) 1909;24:272-80

2 Friedman G, Goldberg SJ. Concurrent and subsequent serum cholesterols of breast and formula fed infants. Am F Clin Nutr 1975;28:42-5.

3 Hodgson PA, Ellefson RD, Elveback LR, Harris LE, Nelson RA, Weidman WH. Comparison of serum cholesterol in children fed high, moderate or low cholesterol milk diets during neonatal period. Metabolism 1976;25:739-46.

4 Andersen GE, Lifschitz C, Früs-Hansen B. Dietary habits and serum lipids during first four years of life. Acta Paediatr Scand 1979;68:165-78.

5 Marmot MG, Page CM, Atkins E, Douglas JWB. Effect of breast feeding on plasma cholesterol and weight in young adults. $\mathcal{F}$ Epidemiol Community plasma cholesterol and
Health 1980;34:164-7.

6 Huttunen JK, Saarinen UM, Kostiainen E, Sümes MA. Fat composition of the infant diet does not influence subsequent serum lipid levels in man. Atherosclerosis 1983;46:87-94.

7 Fomon SJ, Rogers RR, Ziegler EE, Nelson SE, Thomas LN. Indices of fatness and serum cholesterol at age eight years in relation to feeding and growt and serum cholesterol at age eight years in relation

8 Fomon SJ, Bartels DJ. Concentrations of cholesterol in serum of infants in relation to diet. Am Med Assoc f Dis Child 1960;99:43-6.

9 Darmady JM, Fosbrooke AS, Lloyd JK. Prospective study of serum cholesterol levels during first year of life. $B M \mathcal{F}$ 1972;ii:685-8.

10 Van Biervliet JP, Rosseneu M, Caster $\mathbf{H}$. Influence of dietary factors on the plasma lipoprotein composition and content of neonates. Eur f Pedia 1986;144:489-93.

11 Labarthe D, Eissa M, Vara C. Childhood precursors of high blood pressure and elevated cholesterol Ann Rev Public Health 1991;12:519-41.

12 Sporik R, Johnstone JH, Cogswell JJ. Longitudinal study of cholesterol values in 68 children from birth 111 years of age. Arch Dis Child 1991;66:1347.

Mo in 68 children fro adult baboons is influenced by infant diet. 7 Nutr 1990;120:243-51.
14 Hassan AS, Subbiah MTR. Manipulation of cholesterol metabolism in early life: its effect on cholesterol handling and atherosclerosis in adult life. In Subbiah, MTR, ed. Atherosclerosis: a pediatric perspective. London: CRC Press, 1989:221-31.

15 Hahn P. Late effects of early nutrition. In: Subbiah MTR, ed. Atherosclerosis: a pediatric perspective. London: CRC Press, 1989.

16 Barker DJP, Winter PD, Osmond C, Margetts B, Simmonds SJ. Weight in infancy and death from ischaemic heart disease. Lancet 1989;ii:577-80.

17 Barker DJP, Godfrey KM, Fall C, Osmond C, Winter PD, Shaheen SO. Relation of birthweight and childhood respiratory infection to adult lung function and death from chronic obstructive airways disease. BMf 1991; 303:671-5

18 Hales CN, Barker DJP, Clark PMS, Cox LJ, Fall C, Osmond C, et al. Fetal and infant growth and impaired glucose tolerance at age 64 years. $B M J$ 1991;303:1019-22.

19 Office of Population Censuses and Surveys. Classification of occupations 1980 London: HMSO, 1980

20 Allain CC, Poon LS, Chan CSG, Richmond W, Fu PC. Enzymatic determination of serum total cholesterol. Clin Chem 1974;20:470-5.

21 Lie AF, Schmitz JM, Pierre KJ, Gochman N. Cholesterol oxidase-based determination by continuous flow analysis of total and free cholesterol in serum. Clin Chem 1976;22:1627-30.

22 Lopes-Virella MF, Stone P, Ellis S, Colwell JA. Cholesterol determination in high density lipoproteins separated by three different methods. Clin Chem 1977;23:882-4

23 Fossati P, Prencipe L. Serum triglycerides determined colorimetrically with an enzyme that produces hydrogen peroxide. Clin Chem 1982;28:2077-80.

24 Friedwald WT, Levy RI, Fredrickson DS. Estimation of the concentration of low density lipoprotein cholesterol in plasma without use of the preparative ultracentrifuge. Clin Chem 1972;18:499-502.

25 Bhatnagar D, Durrington PN. Clinical value of apolipoprotein measurement. Ann Clin Biochem 1991;28:427-37.

26 Dagen MM, Packard CJ, Shepherd J. A comparison of commercial kits for the measurement of lipoprotein(a). Ann Clin Biochem 1991;28:359-64.

27 Berry G. The analysis of mortality by the subject-years method. Biometric 1983;39:173-84.

28 Barker DJP, Meade TW, Fall C, Lee A, Osmond C, Phipps K, et al. Relation of fetal and infant growth to plasma fibrinogen and factor VII concentration in adult life. $B M F$ 1992;304:148-52.

29 Burnside EM. Annual report of the Lady Inspector of Midwives. In: The county medical officer of health's annual report. Hertfordshire 1915:41.

30 Whitehead R, Paul A. Changes in infant feeding in Britain during the las century. In: Infant feeding and cardiovascular disease. Southampton: MRC Environmental Epidemiology Unit, 1987:1-10. (Medical Research Council Environmental Epidemiology Unit scientific report No 8.)

31 Breast feeding and weaning. In: Series II: Baby. Ten minute talks to centre mothers prepared for the use of health visitors. London: Women Public Health Officers' Association, 1942:1-5.

32 Miller GJ, Martin JC, Webster J, Wilkes H, Miller NE, Wilkinson WH, et al. Association between dietary fat intake and plasma factor VII coagulant activity - a predictor of cardiovascular mortality. Atherosclerosis 1986;60 269-77.

33 Barker DJP, Bull AR, Osmond C, Simmonds SJ. Fetal and placental size and risk of hypertension in adult life. $B M \mathcal{F}$ 1990;301:259-62.

34 Subbiah MTR, Yunker RL, Menkaus A, Poe B. Premature weaning-induced changes of cholesterol metabolism in guinea pigs. Am F Physiol 1985;249. E251-6.

35 Hahn P, Koldovsky O. Late effect of premature weaning on blood cholestero levels in adult rats. Nutrition Reports International 1976;13:87-91.

36 Berenson GS, McMahan CA, Voors AW, Webber LS, Srinivasan SR, Frank $G C$, et al. Dietary studies and the relationship of diet to cardiovascular riskfactor variables in children. In: Cardiovascular risk factors in children. New York: Oxford University Press, 1980:289-307.

37 Kannel WB, Gordon T. The Framingham study: an epidemiological investigation of cardiovascular disease. Section 24. The Framingham diet study: diet and the regulation of serum cholesterol. Washington, DC: Department of Health, regulation of serum cholesterol.

38 Hammans JL, Jordan WE, Stewart RL, Jaulbee JD, Berg RW. Age and die effects on fecal bile acids in infants. I Pediatr Gastroenterol Nutr 1988;7:30-8.

39 Koldovsky O, Thornburg $\mathrm{W}$. Hormones in milk: a review. $\mathcal{I}$ Pedia Gastroenterol Nutr 1987;6:172-96.

40 Salter AM, Fisher SC, Brindley DN. Interactions of triiodothyronine, insulin and dexamethasone on the binding of human LDL to rat hepatocytes in monolayer culture. Atherosclerosis 1988;71:77-80

41 Whitehead RG, Paul AA, Ahmed EA. Weaning practices in the UK an variations in anthropometric development. Acta Paediatr Scand 1986;Supp 323:14-25.

42 Saarinen UM. Need for iron supplementation in infants on prolonged breas feeding. I Pediatr 1978;93:177-80.

43 Belton NR. Rickets - not only the "English disease." Acta Paediatr Scand 1986; Suppl 323:68-75.

44 Cheadle WB. Artificial feeding and food disorders of infants. 6th ed. London: Smith and Elder, 1906

45 Paterson $D$. The next best thing: correct artificial feeding. In: $A$ chance for every child: $a$ report of lectures given at the 9 th winter school for health visitors and school nurses held at Bedford College for Women, University of London, Dec 30th 1929 to fan 10th 1930. London: Women Sanitary Inspectors' and Health Visitors' Association, 1930:22-6.

46 Wang XL, Wilcken DL, Dudman NPB. Apolipoproteins A-1 and B and the B/A-1 ratio in the first year of life. Pediatr Res 1991;30:544-9.

(Accepted 29 fanuary 1992) 